\title{
Maternal cardiovascular disease after twin pregnancies complicated by hypertensive disorders of pregnancy: a population-based cohort study
}

\author{
Liran Hiersch MD, Joel G. Ray MD, Jon Barrett MD, Howard Berger MD, Michael Geary MD, \\ Sarah D. McDonald MD, Christina Diong MSc, Sima Gandhi MSc, Jun Guan MSc, Beth Murray-Davis PhD, \\ Nir Melamed MD; for the DOH-NET (Diabetes, Obesity and Hypertension in Pregnancy Research Network)
}

Cite as: CMAJ 2021 September 20;193:E1448-58. doi: 10.1503/cmaj.202837

\begin{abstract}
Background: People whose singleton pregnancy is affected by hypertensive disorders of pregnancy (HDP) are at risk of future cardiovascular disease. It is unclear, however, whether this association can be extrapolated to twin pregnancies. We aimed to compare the association between HDP and future cardiovascular disease after twin and singleton pregnancies.
\end{abstract}

Methods: We conducted a populationbased retrospective cohort study that included nulliparous people in Ontario, Canada, 1992-2017. We compared the future risk of cardiovascular disease among pregnant people from the following 4 groups: those who delivered a singleton without HDP (referent) and with HDP, and those who delivered twins either with or without HDP.

Results: The populations of the 4 groups were as follows: 1431651 pregnant people in the singleton birth without HDP group; 98631 singleton birth with HDP; 21046 twin birth without HDP; and 4283 twin birth with HDP. The median duration of follow-up was 13 (interquartile range 7-20) years. The incidence rate of cardiovascular disease was lowest among those with a singleton or twin birth without HDP (0.72 and 0.74 per 1000 person-years, respectively). Compared with people with a singleton birth without HDP, the risk of cardiovascular disease was highest among those with a singleton birth and HDP (1.47 per 1000 person-years; adjusted hazard ratio [HR] 1.81 [95\% confidence interval (Cl) 1.72-1.90]), followed by people with a twin pregnancy and HDP (1.07 per 1000 person-years; adjusted HR 1.36 [95\% Cl 1.04-1.77]). The risk of the primary outcome after a twin pregnancy with HDP was lower than that after a singleton pregnancy with HDP (adjusted HR 0.74 [95\% Cl 0.57-0.97]), when compared directly.

Interpretation: In a twin pregnancy, HDP are weaker risk factors for postpartum cardiovascular disease than in a singleton pregnancy. ardiovascular disease has been shown to be the leading cause of death among women. ${ }^{1-3}$ Classic risk factors for cardiovascular disease include obesity, diabetes mellitus, hypertension and family history of cardiovascular disease. ${ }^{3}$ More recently, an association has been established between a history of hypertensive disorders of pregnancy (HDP) - gestational hypertension and pre-eclampsia - and future risk of cardiovascular disease. ${ }^{1,4-11}$ Consequently, some recommend using a history of HDP for cardiovascular disease risk stratification in women. ${ }^{3,12}$

The leading hypothesis for the pathogenesis of HDP is that it results from abnormal placentation due to impaired trophoblast invasion, ${ }^{13-16}$ resulting in reduced placental perfusion. ${ }^{17-19}$ This, in turn, leads to abnormal secretion of the angiogenic factors soluble FMS-like tyrosine kinase 1 (sFlt1) and soluble endoglin (sEng), ${ }^{20}$ which induce endothelial dysfunction and the clinical manifestations of HDP. ${ }^{19,21-24}$ The mechanisms underlying the association between HDP and future cardiovascular disease are under debate. ${ }^{25}$ One hypothesis is that HDP are merely a marker of underlying subclinical or clinical vascular risk factors that predispose a person to both HDP and future cardiovascular disease.

A person who is pregnant with twins is at about 3-4 times higher risk of HDP than a person with a singleton pregnancy, ${ }^{26-33}$ 
with rates of $14 \%$ and $5 \%$, respectively. ${ }^{34}$ The higher risk of HDP in twin pregnancies may be due to higher circulating sFlt1 and sEng owing to greater placental mass in twin pregnancies, ${ }^{35-37}$ and less related to the classic vascular risk factors for HDP in a singleton pregnancy. Therefore, a logical question is whether the established higher risk of future cardiovascular disease after singleton pregnancies with HDP also occurs in twin pregnancies with HDP. Limited data are available to answer this question. ${ }^{38}$ In the current study, we aimed to test the hypothesis that the association between HDP and future cardiovascular disease is less pronounced in twin versus singleton pregnancies.

\section{Methods}

\section{Study design and participants}

We conducted a population-based retrospective cohort study using linked administrative health databases for the province of Ontario, Canada, in which hospital and physician care is publicly funded for all residents. Eligible participants were nulliparous people aged 18-45 years who had a singleton or twin hospital live birth between Apr. 1, 1992, and Mar. 31, 2017. If a person had more than 1 pregnancy, we considered only the first.

We excluded pregnancies with invalid or missing data on gestational age, infant birth weight or infant sex; non-Ontario residents, or people not eligible for the Ontario Health Insurance Plan (OHIP) at the time of delivery; people who died or lost OHIP eligibility within 120 days after the delivery date; and a pregnancy complicated by a stillbirth of 1 or both fetuses. Furthermore, in order to avoid the inclusion of people with pre-existing cardiovascular disease before the index pregnancy, we also excluded those with any recognized form of cardiovascular disease within 2 years before the conception date of the index pregnancy. We present the list of diagnostic and billing codes used to identify cardiovascular disease before the index pregnancy in Appendix 1, Appendix A (available at www.cmaj.ca/lookup/ doi/10.1503/cmaj.202837/tab-related-content). Those codes are used by caregivers at both inpatient and outpatient settings.

\section{Data sources}

We obtained data from Ontario health care administrative databases held at ICES. ${ }^{39}$ These databases contain data on health service utilization by residents of the province and include the Registered Persons Database, which records demographic information for all residents of Ontario, including deaths; and the Ontario Health Insurance Plan provider service claims database, which records all fee-for-service billing and shadow-billing claims submitted by Ontario physicians for inpatient or ambulatory consultations, assessments and diagnostic or therapeutic procedures. ${ }^{40}$ All in-hospital deliveries in Ontario are included in the ICES MOMBABY data set with $98 \%$ deterministic linkage of newborn and maternal hospital records. We obtained all hospital discharges from the Canadian Institutes of Health Information Discharge Abstract Database. We identified all emergency department records using the National Ambulatory Care Reporting System. We used Immigration, Refugees and Citizenship Canada's Permanent Resident
Database to obtain immigration information. Records from the administrative databases are deterministically linked using a patient's encrypted health card number.

We used the International Classification of Diseases (ICD) coding system (9th Revision [ICD-9] before 2002 and the Canadian version, 10th Revision [ICD-10-CA] thereafter) to identify previously validated study exposures ${ }^{41}$ and outcomes. ${ }^{42,43}$ We based residential area income quintile and rurality on Statistics Canada Census data. ${ }^{44}$

\section{Exposures}

The primary exposure was 1 of 4 mutually exclusive states in the index (first) pregnancy: i) singleton birth, no HDP; ii) singleton birth, with HDP; iii) twin birth, no HDP; iv) twin birth, with HDP. We defined HDP as either pre-eclampsia (ICD-9 codes 642.4 or 642.7, and ICD-10 codes 011 , 014 or O15) or gestational hypertension (ICD-9 codes 642.3 or 642.9, and ICD-10 code 013) at the index birth, ascertained from the Canadian Institute for Health Information Discharge Abstract Database. For the primary analysis, we chose people with a first singleton birth without HDP as the reference group, as they provide a large sample of pregnant people who are likely representative of the population at large. For those with a twin pregnancy and HDP, we also estimated the risk of future cardiovascular disease relative to singleton pregnancies and HDP in order to provide a direct comparison between the 2 groups.

As people with pre-eclampsia may have a more pronounced risk of cardiovascular disease than those with gestational hypertension, especially when pre-eclampsia arises preterm, we further considered 2 secondary exposures: any pre-eclampsia, and pre-eclampsia with a preterm birth before 34 weeks' gestation. As gestational age at birth is available only from April 2002 onward, we limited the analysis to births starting Apr. 1, 2002.

\section{Outcomes}

We defined the primary outcome as a cardiovascular disease composite of any future hospital admission for heart failure, cardiac dysrhythmia, coronary artery disease, cerebrovascular disease or peripheral artery disease (Appendix 1, Appendix B). Secondary study outcomes included the individual components of the primary outcome, as well as all-cause mortality. To minimize the immediate effect of HDP and other factors related to pregnancy and delivery on the risk of cardiovascular disease, we assessed study outcomes starting at 120 days after the index birth date.

\section{Statistical analysis}

We used standard descriptive statistics to present the baseline characteristics of the 4 exposure groups. We expressed time-toevent analyses for each study outcome as incidence rates per 1000 person-years, with 95\% confidence intervals ( $\mathrm{Cls})$, starting 120 days after the index birth date. We used Cox proportional hazards models to generate unadjusted and adjusted hazard ratios (HRs), and censored on death, outmigration from the province, or reaching the end of the study period of Mar. 31, 2018. If a person had more than 1 cardiovascular disease event, we counted the first event. A priori, we adjusted HRs for the 
pregnant person's age at the index birth, neighbourhood income quintile, world region of origin, assisted reproductive technology use, and cardiovascular risk factors present before pregnancy, including diabetes mellitus, chronic hypertension, obesity, dyslipidemia, tobacco use or drug dependence, and kidney disease (Appendix 1, Appendix C). We generated time-to-event curves using the Kaplan-Meier procedure and compared exposure groups using the log-rank test.

We analyzed data using the SAS Enterprise Guide statistical software Version 6.1 (Cary, NC).

\section{Ethics approval}

The use of data in this project was authorized under section 45 of Ontario's Personal Health Information Protection Act, in accordance with the Sunnybrook Research Ethics Board.

\section{Results}

There were 3267689 births during the study period. Of the 1555611 nulliparous people who met the study inclusion criteria, $25329(1.6 \%)$ had a twin gestation (Figure 1). The proportions of pregnancies complicated by HDP in the singleton and twin groups were $6.4 \%(98631 / 1530282)$ and $16.9 \%$ (4283/ 25329), respectively (Figure 1 ).

The baseline characteristics of the study groups at the time of the index (first) pregnancy are presented in Table 1. Most people lived in a city and had no prepregnancy morbidity.

The median (interquartile range) duration of follow-up was 13 (7-20) years. The cumulative probability of the cardiovascular disease composite outcome was lowest among people without HDP, either in a singleton or twin pregnancy (incidence rate 0.72 and

All births at 24-42 weeks' gestation during the

study period (Apr. 1, 1992, to Mar. 31, 2017)*

\section{$n=3267689$}

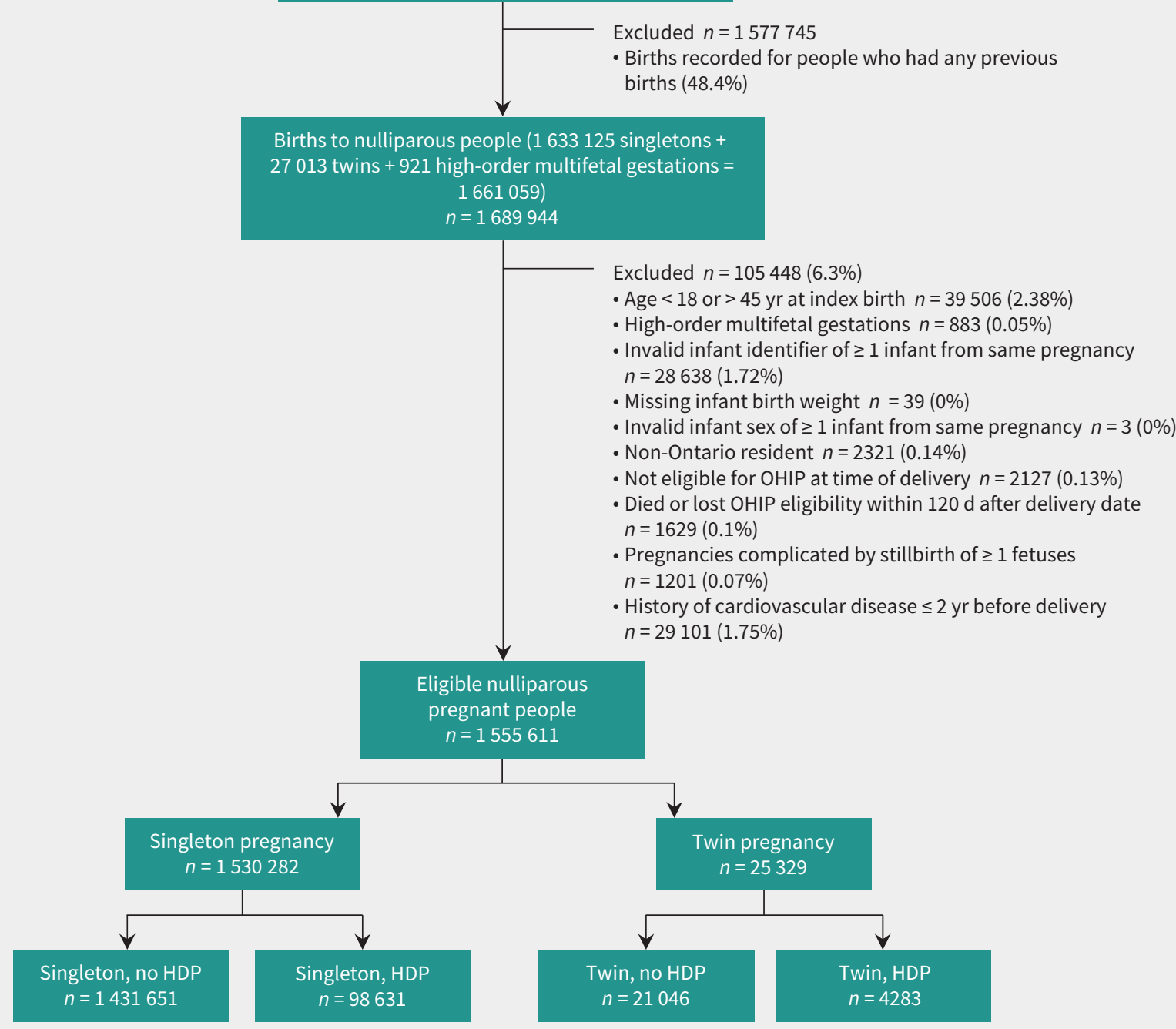

Figure 1: Description of the study groups. Note: HDP = hypertensive disorders of pregnancy, OHIP = Ontario Health Insurance Plan. ${ }^{*}$ For the term "birth," the unit of analysis is newborn rather than pregnancy. Thus, a delivery of twins is counted as 2 births. 
Table 1: Baseline characteristics of the study groups

\begin{tabular}{|c|c|c|c|c|}
\hline Characteristic & $\begin{array}{l}\text { No. }(\%)^{\star} \text { of } \\
\text { singleton births, } \\
\text { no HDP } \\
n=1431651\end{array}$ & $\begin{array}{l}\text { No. }(\%)^{\star} \text { of } \\
\text { singleton births, } \\
\text { with HDP } \\
n=98631\end{array}$ & $\begin{array}{l}\text { No. }(\%)^{\star} \text { of } \\
\text { twin births, } \\
\text { no HDP } \\
n=21046\end{array}$ & $\begin{array}{l}\text { No. }(\%)^{\star} \text { of } \\
\text { twin births, } \\
\text { with HDP } \\
n=4283\end{array}$ \\
\hline Age at delivery, mean \pm SD, yr & $28.8 \pm 5.4$ & $29.2 \pm 5.5$ & $30.7 \pm 5.2$ & $31.1 \pm 5.4$ \\
\hline $18-24$ & $319126(22.3)$ & $20519(20.8)$ & 2616 (12.4) & 485 (11.3) \\
\hline $25-40$ & $1091669(76.3)$ & $75871(76.9)$ & $17868(84.9)$ & $3615(84.4)$ \\
\hline$>40$ & $20856(1.5)$ & $2241(2.3)$ & $562(2.7)$ & $183(4.3)$ \\
\hline \multicolumn{5}{|l|}{ World region of origin } \\
\hline Canada & $1050177(73.4)$ & $80537(81.7)$ & $16172(76.8)$ & $3518(82.1)$ \\
\hline Africa and Middle East & $56757(4.0)$ & $2557(2.6)$ & $926(4.4)$ & $124(2.9)$ \\
\hline Americas & 50256 (3.5) & $3149(3.2)$ & $623(3.0)$ & $118(2.8)$ \\
\hline Asia and Pacific & $207322(14.5)$ & $8961(9.1)$ & $2280(10.8)$ & $362(8.5)$ \\
\hline Europe & $60521(4.2)$ & $2969(3.0)$ & $925(4.4)$ & $139(3.2)$ \\
\hline United States & $6541(0.5)$ & $454(0.5)$ & $118(0.6)$ & $22(0.5)$ \\
\hline Not stated & $77(0.0)$ & $\leq 5 \S$ & $\leq 5 \S$ & $\leq 5 \S$ \\
\hline \multicolumn{5}{|c|}{ Neighbourhood-level household income } \\
\hline Quintile 1 (lowest) & $337527(23.6)$ & $22028(22.3)$ & $3938(18.7)$ & $714(16.7)$ \\
\hline Quintile 2 & $299580(20.9)$ & $20795(21.1)$ & $4126(19.6)$ & $800(18.7)$ \\
\hline Quintile 3 & $286262(20.0)$ & $20576(20.9)$ & $4226(20.1)$ & $904(21.1)$ \\
\hline Quintile 4 & $280197(19.6)$ & $19793(20.1)$ & $4659(22.1)$ & $963(22.5)$ \\
\hline Quintile 5 (highest) & $221176(15.4)$ & $14939(15.1)$ & $4027(19.1)$ & $882(20.6)$ \\
\hline Unknown & $6909(0.5)$ & $500(0.5)$ & $70(0.3)$ & $20(0.5)$ \\
\hline Rural residence at delivery & $78470(5.5)$ & $6481(6.6)$ & $1107(5.3)$ & $238(5.6)$ \\
\hline \multicolumn{5}{|l|}{ Prepregnancy morbidity } \\
\hline Diabetes & $13902(1.0)$ & $2759(2.8)$ & $280(1.3)$ & $101(2.4)$ \\
\hline Chronic hypertension & $39389(2.8)$ & $9388(9.5)$ & $702(3.3)$ & $312(7.3)$ \\
\hline $\begin{array}{l}\text { Tobacco use or drug } \\
\text { dependence }\end{array}$ & $50694(3.5)$ & $3767(3.8)$ & $749(3.6)$ & $147(3.4)$ \\
\hline Kidney disease & $4110(0.3)$ & $622(0.6)$ & $71(0.3)$ & $30(0.7)$ \\
\hline $\begin{array}{l}\text { Assisted reproductive } \\
\text { technology }\end{array}$ & $11980(0.8)$ & $1387(1.4)$ & $2596(12.3)$ & $613(14.3)$ \\
\hline \multicolumn{5}{|l|}{ Gestational age at birth, wk } \\
\hline$<37$ & $64071(4.5)$ & $13666(13.9)$ & $10081(47.9)$ & $2514(58.7)$ \\
\hline$<34$ & $17867(1.2)$ & $5060(5.1)$ & $4008(19.0)$ & 594 (13.9) \\
\hline \multicolumn{5}{|l|}{ Neonatal characteristics $\dagger$} \\
\hline Female infant & $698713(48.8)$ & $47191(47.8)$ & $20649(49.1)$ & $4320(50.4)$ \\
\hline Birth weight, mean \pm SD, g & $3367 \pm 545$ & $3159 \pm 742$ & $2358 \pm 656$ & $2365 \pm 543$ \\
\hline$\leq$ Tenth percentilef & $104987(7.3)$ & 19663 (19.9) & $27377(65.0)$ & $6007(70.1)$ \\
\hline$\leq$ Third percentilef & $24470(1.7)$ & $8386(8.5)$ & $11975(28.4)$ & $2308(26.9)$ \\
\hline $\begin{array}{l}\text { Duration of follow-up of } \\
\text { pregnant person, median } \\
\text { (IQR), yr }\end{array}$ & $13(7-20)$ & $13(7-20)$ & $12(7-18)$ & $12(7-19)$ \\
\hline \multicolumn{5}{|c|}{$\begin{array}{l}\text { Note: HDP = hypertensive disorders of pregnancy, } \mathrm{IQR}=\text { interquartile range, } \mathrm{SD}=\text { standard deviation. } \\
\text { *Unless otherwise specified. } \\
\text { tThe unit of analysis for neonatal characteristics is infant rather than pregnancy. } \\
\text { †Based on the Canadian growth reference of Kramer and colleagues. }{ }^{45} \\
\text { §Data suppressed because of small cell size. }\end{array}$} \\
\hline
\end{tabular}


0.74 per 1000 person-years, respectively), highest in those with a singleton birth and HDP (1.47 per 1000 person-years), and intermediate in those with a twin birth and HDP (1.07 per 1000 personyears) (Figure 2 and Table 2). Relative to a singleton birth without HDP, the corresponding adjusted HRs were 1.81 (95\% Cl 1.72-1.90) in singleton pregnancies with HDP and $1.36(95 \% \mathrm{Cl} 1.04-1.77)$ in twin pregnancies with HDP (Table 2, Figure 3). When we compared the risk of the primary outcome in the twin pregnancy with HDP group versus the singleton pregnancy with HDP group, the adjusted HR was 0.74 (95\% Cl 0.57-0.97) (Appendix 1, Appendix D).

Hypertensive disorders of pregnancy were associated with all the secondary outcomes in singleton pregnancies, but not in twin pregnancies (Table 3). For instance, relative to a singleton birth without HDP, the corresponding adjusted HRs for heart failure, coronary artery disease and cerebrovascular disease were 2.20 (95\% Cl 1.92-2.51), 1.91 (95\% Cl 1.80-2.03) and $2.13(95 \% \mathrm{Cl}$ $1.88-2.42)$, in singleton pregnancies with $\mathrm{HDP}$ and $1.74(95 \% \mathrm{Cl}$ $0.87-3.48), 1.37$ (95\% Cl 0.98-1.91) and 1.51 (95\% Cl 0.76-3.04) in twin pregnancies with HDP, respectively (Table 4).

When we calculated the risk of the secondary outcomes in the twin pregnancy with HDP group using the singleton pregnancy with HDP group as the reference, the effect size ranged from 0.36 to 0.83 (indicating a lower risk of the secondary outcomes in twin pregnancy with HDP compared with the reference group), but none of these associations were statistically significant (Appendix 1, Appendix E).

In both singleton and twin gestations, the associations between either pre-eclampsia or pre-eclampsia with preterm birth before 34 weeks and the primary cardiovascular disease composite were similar in direction and magnitude to those observed for the primary exposure of HDP (Table 2; Appendix 1, Appendices D and F).

Finally, to determine whether age during pregnancy modifies the associations described above, we stratified the analysis for the primary outcome by age (Table 4). Although the incidence rates were higher among people aged 35 years or older than those younger than 35 years, the risk of the primary outcome in each of the groups in relation to the referent group (singleton pregnancies without HDP) remained similar (Table 4).

\section{Interpretation}

\section{Main findings}

In agreement with our hypothesis, we found that those with a history of HDP in a twin pregnancy were at an intermediate risk of the primary composite cardiovascular disease outcome, with

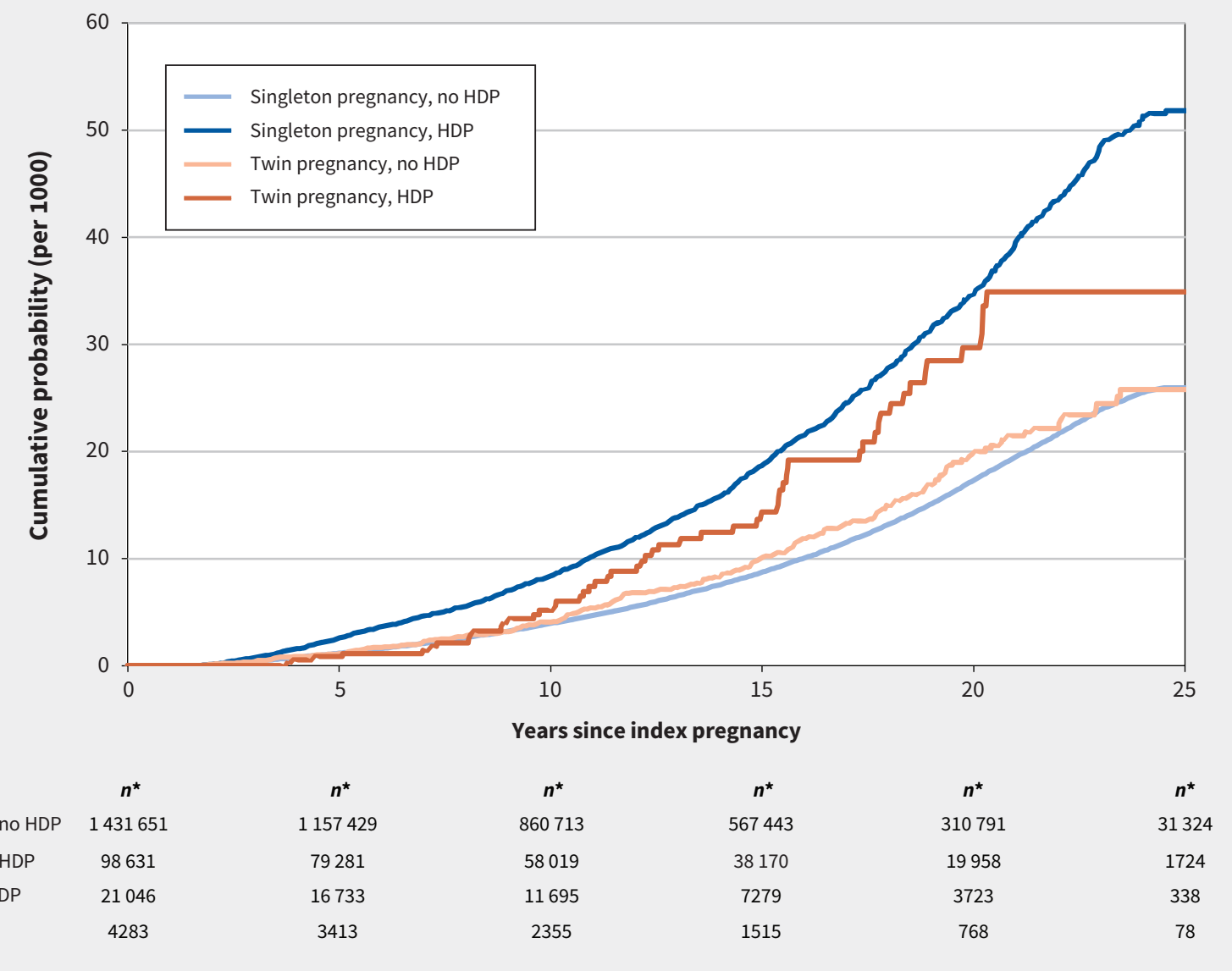

Figure 2: Cumulative probability of the composite primary outcome by plurality and hypertensive disorders of pregnancy (HDP; gestational hypertension or pre-eclampsia) in a first pregnancy. Note: The cumulative probability curves of the composite cardiovascular outcome are presented for twin and singleton pregnancies with and without HDP. ${ }^{*} n=$ number at risk at each 5 -year interval shown. Differences between the 4 groups were statistically significant $(p<0.001$, log-rank test). 


\begin{tabular}{|c|c|c|c|c|c|c|}
\hline \multirow[b]{2}{*}{ Exposure } & \multicolumn{2}{|c|}{$\begin{array}{c}\text { Singleton birth, } \\
\text { no hypertensive complication } \\
\text { (referent) }\end{array}$} & \multicolumn{4}{|c|}{$\begin{array}{l}\text { Singleton birth, } \\
\text { with hypertensive complication }\end{array}$} \\
\hline & No. events & $\begin{array}{l}\text { Incidence rate } \\
\text { (per } 1000 \\
\text { person-year, } \\
95 \% \mathrm{Cl} \text { ) }\end{array}$ & No. events & $\begin{array}{l}\text { Incidence rate } \\
\text { (per } 1000 \\
\text { person-year, } \\
95 \% \mathrm{Cl} \text { ) }\end{array}$ & $\begin{array}{l}\text { Unadjusted HR } \\
(95 \% \mathrm{CI})\end{array}$ & $\begin{array}{l}\text { Adjusted HR† } \\
(95 \% \mathrm{Cl})\end{array}$ \\
\hline $\begin{array}{l}\text { Any hypertensive } \\
\text { disorder of pregnancy }\end{array}$ & $\begin{array}{c}13076 / \\
1431651\end{array}$ & $\begin{array}{c}0.72 \\
(0.71-0.73)\end{array}$ & $\begin{array}{l}1811 / \\
98631\end{array}$ & $\begin{array}{c}1.47 \\
(1.40-1.54)\end{array}$ & $\begin{array}{c}2.08 \\
(1.98-2.18)\end{array}$ & $\begin{array}{c}1.81 \\
(1.72-1.90)\end{array}$ \\
\hline Pre-eclampsia & $\begin{array}{c}13840 / \\
1489419\end{array}$ & $\begin{array}{c}0.73 \\
(0.72-0.75)\end{array}$ & $\begin{array}{l}1047 / \\
40863\end{array}$ & $\begin{array}{c}1.73 \\
(1.63-1.84)\end{array}$ & $\begin{array}{c}2.09 \\
(1.97-2.23)\end{array}$ & $\begin{array}{c}1.83 \\
(1.72-1.95)\end{array}$ \\
\hline $\begin{array}{l}\text { Preterm pre- } \\
\text { eclampsiał }\end{array}$ & $\begin{array}{l}255 / \\
18802\end{array}$ & $\begin{array}{c}1.17 \\
(1.03-1.32)\end{array}$ & $\begin{array}{l}126 / \\
4125\end{array}$ & $\begin{array}{c}2.44 \\
(2.05-2.91)\end{array}$ & $\begin{array}{c}1.99 \\
(1.61-2.46)\end{array}$ & $\begin{array}{c}1.84 \\
(1.48-2.30)\end{array}$ \\
\hline
\end{tabular}

Table 2 (part 2 of 2): Risk of the primary composite outcome in relation to plurality and the hypertensive disorders of pregnancy using people with a singleton birth with no hypertensive disorders as the reference group*

\begin{tabular}{|c|c|c|c|c|c|c|c|c|}
\hline \multirow[b]{2}{*}{ Exposure } & \multicolumn{4}{|c|}{$\begin{array}{l}\text { Twin birth, } \\
\text { no hypertensive complication }\end{array}$} & \multicolumn{4}{|c|}{$\begin{array}{l}\text { Twin birth, } \\
\text { with hypertensive complication }\end{array}$} \\
\hline & $\begin{array}{l}\text { No. } \\
\text { events }\end{array}$ & $\begin{array}{l}\text { Incidence } \\
\text { rate } \\
\text { (per } 1000 \\
\text { person- } \\
\text { year, 95\% } \\
\text { Cl) }\end{array}$ & $\begin{array}{c}\text { Unadjusted } \\
\text { HR } \\
(95 \%-\mathrm{Cl})\end{array}$ & $\begin{array}{l}\text { Adjusted } \\
\text { HR† (95\% } \\
\quad \text { CI) }\end{array}$ & No. events & $\begin{array}{l}\text { Incidence } \\
\text { rate } \\
\text { (per } 1000 \\
\text { person- } \\
\text { year, 95\% } \\
\text { Cl) }\end{array}$ & $\begin{array}{c}\text { Unadjusted } \\
\text { HR } \\
(95 \% \mathrm{Cl})\end{array}$ & $\begin{array}{c}\text { Adjusted } \\
\text { HR† ( } 95 \% \\
\text { CI) }\end{array}$ \\
\hline $\begin{array}{l}\text { Any hypertensive } \\
\text { disorder of pregnancy }\end{array}$ & $\begin{array}{c}185 / \\
21046\end{array}$ & $\begin{array}{c}0.74 \\
(0.64-0.85)\end{array}$ & $\begin{array}{c}1.08 \\
(0.93-1.25)\end{array}$ & $\begin{array}{c}1.02 \\
(0.89-1.18)\end{array}$ & $55 / 4283$ & $\begin{array}{c}1.07 \\
(0.82-1.40)\end{array}$ & $\begin{array}{c}1.56 \\
(1.20-2.04)\end{array}$ & $\begin{array}{c}1.36 \\
(1.04-1.77)\end{array}$ \\
\hline Pre-eclampsia & $\begin{array}{c}200 / \\
22963\end{array}$ & $\begin{array}{c}0.74 \\
(0.64-0.85)\end{array}$ & $\begin{array}{c}1.06 \\
(0.92-1.22)\end{array}$ & $\begin{array}{c}1.01 \\
(0.87-1.16)\end{array}$ & $40 / 2366$ & $\begin{array}{c}1.28 \\
(0.94-1.75)\end{array}$ & $\begin{array}{c}1.65 \\
(1.21-2.26)\end{array}$ & $\begin{array}{c}1.42 \\
(1.04-1.93)\end{array}$ \\
\hline $\begin{array}{l}\text { Preterm pre- } \\
\text { eclampsiał }\end{array}$ & $\begin{array}{c}40 / \\
4180\end{array}$ & $\begin{array}{c}0.84 \\
(0.62-1.15)\end{array}$ & $\begin{array}{c}0.73 \\
(0.53-1.02)\end{array}$ & $\begin{array}{c}0.77 \\
(0.55-1.07)\end{array}$ & $8 / 422$ & $\begin{array}{c}1.65 \\
(0.83-3.30)\end{array}$ & $\begin{array}{c}1.39 \\
(0.69-2.81)\end{array}$ & $\begin{array}{c}1.10 \\
(0.54-2.23)\end{array}$ \\
\hline
\end{tabular}

the risk being lower than in those with HDP in a singleton pregnancy, but higher than in people with a twin pregnancy without HDP. The association was not affected by the severity of hypertensive complications.

\section{Comparison with other studies}

The association of HDP with future cardiovascular disease is well established. ${ }^{1,4,6-10,46,47}$ In a recent meta-analysis, women with a history of pre-eclampsia had a relative risk of 2.5 for future coronary artery disease, 4.2 for heart failure, and 2.2 for cardiovascular death. ${ }^{47}$ Given the relatively high prevalence of HDP in twin pregnancies (16.9\% in the current study, which is in agreement with previous reports ${ }^{34}$ ), it is important to determine whether this association can be extrapolated to people who experienced HDP in a twin pregnancy. As previous studies were either limited to people with singleton gestations ${ }^{48,49}$ or did not differentiate between people with singleton and twin gestations, our findings add to the literature by qualifying the relationship between HDP and future cardiovascular disease among people who have a twin pregnancy. ${ }^{4,6,7,9,11} \mathrm{~A}$ recently published cohort study reported that pre-eclampsia in women with multifetal pregnancy was not associated with a higher risk of future cardiovascular disease. ${ }^{38}$ However, that study addressed only pre-eclampsia (and not gestational hypertension) as the exposure variable, and did not adjust for known cardiovascular risk factors such as diabetes mellitus and kidney disease. Our results confirm previous findings regarding the association of HDP in singleton gestations with future maternal cardiovascular disease but suggest that the magnitude of this association is lower in those who experienced HDP during a twin pregnancy. Although the adjusted hazard ratio for future cardiovascular disease in the twin pregnancy with HDP group 


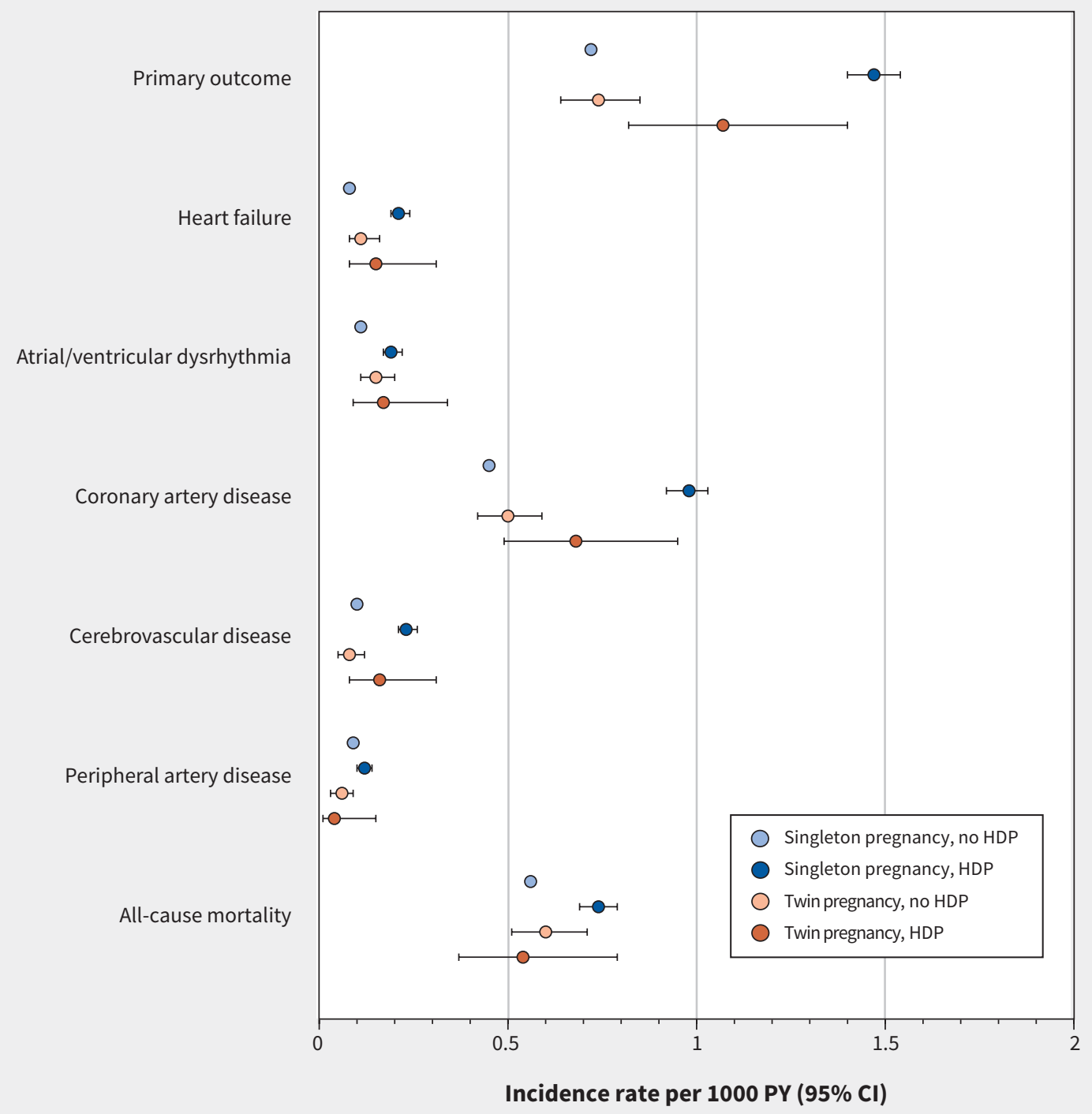

Figure 3: Incidence rate of cardiovascular morbidity or death by plurality and hypertensive disorders of pregnancy (HDP; gestational hypertension or pre-eclampsia) in the first pregnancy. The incidence rates of the composite cardiovascular outcome are presented for people with twin and singleton pregnancies with and without HDP. Values are presented as rate per 1000 person-years (PYs) with 95\% confidence intervals $(\mathrm{Cl})$.

did not differ significantly from that found in the singleton pregnancy with HDP group (as reflected by the overlapping Cls), this is likely to be due to insufficient power, given the considerable differences in the point estimates of the hazard ratios, and as demonstrated by the differences in the incidence rates and the survival curves (Figure 2) between the twin pregnancy with HDP and singleton pregnancy with HDP groups. Furthermore, the risk of the primary outcome in twin pregnancies with HDP was significantly lower than in singleton pregnancies with HDP (adjusted HR 0.74 [95\% Cl 0.57-0.97]).

The mechanisms underlying the association between HDP and future cardiovascular disease remain unclear. ${ }^{1}$ One explanation is that HDP is associated with a release of inflammatory and anti-angiogenic factors, ${ }^{50}$ and although these changes usually resolve postpartum, some patients experience sustained vascular damage and endothelial dysfunction, which may predispose them to future cardiovascular disease. , $46,51,52$ The differences in the associations between HDP and future cardiovascular disease between twin and singleton pregnancies identified in our study argues against a direct causal relationship between HDP and future maternal cardiovascular disease, however, because the association between HDP and future cardiovascular disease would be expected to be similar in people who had delivered twins and singletons, respectively, if that was the case. Furthermore, the lack of a "dose-response" relationship between the severity of HDP and future cardiovascular disease, as we observed, further argues against a direct causal relationship between HDP and future cardiovascular disease.

A second explanation for the association between HDP and future cardiovascular disease attributes this association to the 
Table 3 (part 1 of 2): Risk of the secondary outcomes in relation to plurality and the hypertensive disorders of pregnancy using people with a singleton birth with no hypertensive disorders as the reference group

\begin{tabular}{|c|c|c|c|c|c|c|}
\hline \multirow[b]{2}{*}{ Outcome } & \multicolumn{2}{|c|}{$\begin{array}{c}\text { Singleton birth, } \\
\text { no HDP } \\
\text { (referent) } \\
n=1431651\end{array}$} & \multicolumn{4}{|c|}{$\begin{array}{l}\text { Singleton birth, } \\
\text { with HDP } \\
n=98631\end{array}$} \\
\hline & No. events & $\begin{array}{l}\text { Incidence rate } \\
\text { (per } 1000 \\
\text { person-year, } \\
95 \% \mathrm{Cl} \text { ) }\end{array}$ & No. events & $\begin{array}{l}\text { Incidence rate } \\
\text { (per } 1000 \\
\text { person-year, } \\
95 \% \mathrm{CI} \text { ) }\end{array}$ & $\begin{array}{l}\text { Unadjusted HR } \\
\qquad(95 \% \mathrm{Cl})\end{array}$ & $\begin{array}{l}\text { Adjusted HR* } \\
(95 \% \mathrm{CI})\end{array}$ \\
\hline Heart failure & 1466 & $\begin{array}{c}0.08 \\
(0.08-0.08)\end{array}$ & 266 & $\begin{array}{c}0.21 \\
(0.19-0.24)\end{array}$ & $\begin{array}{c}2.70 \\
(2.37-3.08)\end{array}$ & $2.20(1.92-2.51)$ \\
\hline $\begin{array}{l}\text { Cardiac } \\
\text { dysrhythmia }\end{array}$ & 1976 & $\begin{array}{c}0.11 \\
(0.10-0.11)\end{array}$ & 236 & $\begin{array}{c}0.19 \\
(0.17-0.22)\end{array}$ & $\begin{array}{c}1.78 \\
(1.55-2.03)\end{array}$ & $1.55(1.34-1.77)$ \\
\hline $\begin{array}{l}\text { Coronary artery } \\
\text { disease }\end{array}$ & 8139 & $\begin{array}{c}0.45 \\
(0.44-0.46)\end{array}$ & 1208 & $\begin{array}{c}0.98 \\
(0.92-1.03)\end{array}$ & $\begin{array}{c}2.23 \\
(2.10-2.37)\end{array}$ & $\begin{array}{c}1.91 \\
(1.80-2.03)\end{array}$ \\
\hline $\begin{array}{l}\text { Cerebrovascular } \\
\text { disease }\end{array}$ & 1764 & $\begin{array}{c}0.10 \\
(0.09-0.10)\end{array}$ & 290 & $\begin{array}{c}0.23 \\
(0.21-0.26)\end{array}$ & $\begin{array}{c}2.45 \\
(2.16-2.77)\end{array}$ & $\begin{array}{c}2.13 \\
(1.88-2.42)\end{array}$ \\
\hline $\begin{array}{l}\text { Peripheral artery } \\
\text { disease }\end{array}$ & 1608 & $\begin{array}{c}0.09 \\
(0.08-0.09)\end{array}$ & 149 & $\begin{array}{c}0.12 \\
(0.10-0.14)\end{array}$ & $\begin{array}{c}1.37 \\
(1.16-1.62)\end{array}$ & $\begin{array}{c}1.24 \\
(1.04-1.46)\end{array}$ \\
\hline $\begin{array}{l}\text { All-cause } \\
\text { mortality }\end{array}$ & 10183 & $\begin{array}{c}0.56 \\
(0.55-0.57)\end{array}$ & 922 & $\begin{array}{c}0.74 \\
(0.69-0.79)\end{array}$ & $\begin{array}{c}1.35 \\
(1.26-1.44)\end{array}$ & $\begin{array}{c}1.23 \\
(1.14-1.31)\end{array}$ \\
\hline
\end{tabular}

Table 3 (part 2 of 2): Risk of the secondary outcomes in relation to plurality and the hypertensive disorders of pregnancy using people with a singleton birth with no hypertensive disorders as the reference group

\begin{tabular}{|c|c|c|c|c|c|c|c|c|}
\hline \multirow[b]{2}{*}{ Outcome } & \multicolumn{4}{|c|}{$\begin{array}{c}\text { Twin birth, } \\
\text { no HDP } \\
n=21046\end{array}$} & \multicolumn{4}{|c|}{$\begin{array}{c}\text { Twin birth, } \\
\text { with HDP } \\
n=4283\end{array}$} \\
\hline & No. events & $\begin{array}{l}\text { Incidence } \\
\text { rate } \\
\text { (per } 1000 \\
\text { person- } \\
\text { year, } 95 \% \\
\text { CI) }\end{array}$ & $\begin{array}{c}\text { Unadjusted } \\
\text { HR } \\
(95 \% \mathrm{Cl})\end{array}$ & $\begin{array}{c}\text { Adjusted } \\
\text { HR }^{\star}(95 \% \\
\text { CI) }\end{array}$ & No. events & $\begin{array}{l}\text { Incidence } \\
\text { rate } \\
\text { (per } 1000 \\
\text { person- } \\
\text { year, 95\% } \\
\text { CI) }\end{array}$ & $\begin{array}{c}\text { Unadjusted } \\
\text { HR } \\
(95 \% \mathrm{CI})\end{array}$ & $\begin{array}{c}\text { Adjusted } \\
\mathrm{HR}^{\star}(95 \% \\
\text { CI) }\end{array}$ \\
\hline Heart failure & 28 & $\begin{array}{c}0.11 \\
(0.08-0.16)\end{array}$ & $\begin{array}{c}1.46 \\
(1.00-2.11)\end{array}$ & $\begin{array}{c}1.37 \\
(0.92-2.01)\end{array}$ & 8 & $\begin{array}{c}0.15 \\
(0.08-0.31)\end{array}$ & $\begin{array}{c}2.02 \\
(1.01-4.05)\end{array}$ & $\begin{array}{c}1.74 \\
(0.87-3.48)\end{array}$ \\
\hline $\begin{array}{l}\text { Cardiac } \\
\text { dysrhythmia }\end{array}$ & 28 & $\begin{array}{c}0.15 \\
(0.11-0.20)\end{array}$ & $\begin{array}{c}1.43 \\
(1.03-1.97)\end{array}$ & $\begin{array}{c}1.33 \\
(0.96-1.85)\end{array}$ & 9 & $\begin{array}{c}0.17 \\
(0.09-0.34)\end{array}$ & $\begin{array}{c}1.68 \\
(0.87-3.24)\end{array}$ & $\begin{array}{c}1.44 \\
(0.75-2.77)\end{array}$ \\
\hline $\begin{array}{l}\text { Coronary artery } \\
\text { disease }\end{array}$ & 125 & $\begin{array}{c}0.50 \\
(0.42-0.59)\end{array}$ & $\begin{array}{c}1.19 \\
(0.99-1.41)\end{array}$ & $\begin{array}{c}1.11 \\
(0.93-1.33)\end{array}$ & 35 & $\begin{array}{c}0.68 \\
(0.49-0.95)\end{array}$ & $\begin{array}{c}1.61 \\
(1.16-2.25)\end{array}$ & $\begin{array}{c}1.37 \\
(0.98-1.91)\end{array}$ \\
\hline $\begin{array}{l}\text { Cerebrovascular } \\
\text { disease }\end{array}$ & 19 & $\begin{array}{c}0.08 \\
(0.05-0.12)\end{array}$ & $\begin{array}{c}0.82 \\
(0.52-1.28)\end{array}$ & $\begin{array}{c}0.80 \\
(0.51-1.26)\end{array}$ & 8 & $\begin{array}{c}0.16 \\
(0.08-0.31)\end{array}$ & $\begin{array}{c}1.67 \\
(0.83-3.35)\end{array}$ & $\begin{array}{c}1.51 \\
(0.76-3.04)\end{array}$ \\
\hline $\begin{array}{l}\text { Peripheral artery } \\
\text { disease }\end{array}$ & 14 & $\begin{array}{c}0.06 \\
(0.03-0.09)\end{array}$ & $\begin{array}{c}0.64 \\
(0.38-1.09)\end{array}$ & $\begin{array}{c}0.63 \\
(0.37-1.06)\end{array}$ & $\leq 5 \dagger$ & $\begin{array}{c}0.04 \\
(0.01-0.15)\end{array}$ & $\begin{array}{c}0.45 \\
(0.11-1.80)\end{array}$ & $\begin{array}{c}0.41 \\
(0.10-1.64)\end{array}$ \\
\hline $\begin{array}{l}\text { All-cause } \\
\text { mortality }\end{array}$ & 152 & $\begin{array}{c}0.60 \\
(0.51-0.71)\end{array}$ & $\begin{array}{c}1.13 \\
(0.96-1.33)\end{array}$ & $\begin{array}{c}1.09 \\
(0.92-1.28)\end{array}$ & 28 & $\begin{array}{c}0.54 \\
(0.37-0.79)\end{array}$ & $\begin{array}{c}1.01 \\
(0.70-1.47)\end{array}$ & $\begin{array}{c}0.93 \\
(0.64-1.35)\end{array}$ \\
\hline
\end{tabular}

Note: $\mathrm{Cl}$ = confidence interval, $\mathrm{HDP}=$ hypertensive disorders of pregnancy (pre-eclampsia or gestational hypertension), $\mathrm{HR}=$ hazard ratio.

*Adjusted for age at first birth, neighbourhood income quintile, world region of origin, assisted reproductive technology, and cardiovascular risk factors present at baseline before the first pregnancy.

tData suppressed because of small cell size.

presence of underlying clinical or subclinical maternal vascular risk factors that predispose patients to both HDP and future cardiovascular disease (Appendix 1, Appendix G). Our observation of a lower association of HDP with future cardiovascular disease in people who had delivered twins compared with singletons provides support for this explanation. In people who have delivered twins, where the pathogenesis of HDP is heterogeneous and some of it likely attributed to transient factors such as increased placental 
Table 4 (part 1 of 2): Risk of the primary composite outcome in relation to plurality and the hypertensive disorders of pregnancy using people with a singleton birth with no hypertensive disorders as the referent, stratified by age of the pregnant person at delivery*

Singleton birth, no hypertensive complication (referent)

Incidence rate (per 1000 person-year,

No. events 95\% Cl)
1275539

Any hypertensive

disorder of pregnancy

Pre-eclampsia

1325408

15804

Preterm pre-

eclampsiał

Age of pregnant person $>35 \mathrm{yr}$

Any hypertensive

disorder of pregnancy

Pre-eclampsia

156112

164011

2998

Preterm pre-

eclampsiał
0.65

(0.64-0.66)

0.66

(0.65-0.68)

0.99
$(0.86-1.15)$

1.32

(1.27-1.37)

$1.37(1.32-1.42)$

2.16

(1.71-2.72)
Singleton birth, with hypertensive complication

Incidence rate
(per 1000
person-year, $95 \% \mathrm{Cl}$ )

Unadjusted HR $(95 \% \mathrm{Cl})$

Adjusted HR†

No. events

85434

1.28

2.00

1.77

(1.22-1.35)

(1.89-2.11)

(1.68-1.88)

1.54

2.06

1.83

(1.44-1.65)

(1.92-2.21)

(1.70-1.96)

2.17

2.07

1.95

(1.77-2.65)

(1.61-2.65)

(1.51-2.52)

$\begin{array}{cc}13197 & (2.55-3.08) \\ 5298 & 3.16 \\ & (2.77-3.61) \\ 725 & 3.87 \\ & (2.74-5.48)\end{array}$

2.17

1.86

(1.96-2.41)

(1.67-2.07)

2.08

1.75

$(1.81-2.39)$

$(1.53-2.02)$

1.73

1.49

$(1.14-2.63)$

Table 4 (part 2 of 2): Risk of the primary composite outcome in relation to plurality and the hypertensive disorders of pregnancy using people with a singleton birth with no hypertensive disorders as the referent, stratified by age of the pregnant person at delivery*

\begin{tabular}{|c|c|c|c|c|c|c|c|c|}
\hline & \multicolumn{4}{|c|}{$\begin{array}{l}\text { Twin birth, } \\
\text { no hypertensive complication }\end{array}$} & \multicolumn{4}{|c|}{$\begin{array}{l}\text { Twin birth, } \\
\text { with hypertensive complication }\end{array}$} \\
\hline Exposure & $\begin{array}{l}\text { No. } \\
\text { events }\end{array}$ & $\begin{array}{l}\text { Incidence } \\
\text { rate } \\
\text { (per } 1000 \\
\text { person- } \\
\text { year, } 95 \% \\
\text { CI) }\end{array}$ & $\begin{array}{c}\text { Unadjusted } \\
\text { HR } \\
(95 \% \mathrm{Cl})\end{array}$ & $\begin{array}{c}\text { Adjusted } \\
\text { HR† (95\% } \\
\text { CI) }\end{array}$ & No. events & $\begin{array}{l}\text { Incidence } \\
\text { rate } \\
\text { (per } 1000 \\
\text { person- } \\
\text { year, } 95 \% \\
\text { Cl) }\end{array}$ & $\begin{array}{c}\text { Unadjusted } \\
\text { HR } \\
(95 \% \mathrm{Cl})\end{array}$ & $\begin{array}{c}\text { Adjusted } \\
\text { HR† (95\% } \\
\text { CI) }\end{array}$ \\
\hline \multicolumn{9}{|c|}{ Age of pregnant person $\leq 35 \mathrm{yr}$} \\
\hline $\begin{array}{l}\text { Any hypertensive } \\
\text { disorder of pregnancy }\end{array}$ & 17351 & $\begin{array}{c}0.63 \\
(0.53-0.75)\end{array}$ & $\begin{array}{c}1.01 \\
(0.85-1.20)\end{array}$ & $\begin{array}{c}0.97 \\
(0.82-1.15)\end{array}$ & 3381 & $\begin{array}{c}0.92 \\
(0.67-1.26)\end{array}$ & $\begin{array}{c}1.46 \\
(1.06-1.99)\end{array}$ & $\begin{array}{c}1.30 \\
(0.95-1.78)\end{array}$ \\
\hline Pre-eclampsia & 18850 & $\begin{array}{c}0.64 \\
(0.55-0.76)\end{array}$ & $\begin{array}{c}1.01 \\
(0.86-1.19)\end{array}$ & $\begin{array}{c}0.98 \\
(0.83-1.15)\end{array}$ & 1882 & $\begin{array}{c}1.00 \\
(0.68-1.47)\end{array}$ & $\begin{array}{c}1.40 \\
(0.95-2.06)\end{array}$ & $\begin{array}{c}1.23 \\
(0.84-1.81)\end{array}$ \\
\hline $\begin{array}{l}\text { Preterm pre- } \\
\text { eclampsiał }\end{array}$ & 3529 & $\begin{array}{c}0.73 \\
(0.51-1.05)\end{array}$ & $\begin{array}{c}0.75 \\
(0.51-1.10)\end{array}$ & $\begin{array}{c}0.79 \\
(0.54-1.17)\end{array}$ & 310 & $\begin{array}{c}1.32 \\
(0.55-3.17)\end{array}$ & $\begin{array}{c}1.27 \\
(0.52-3.10)\end{array}$ & $\begin{array}{c}1.06 \\
(0.43-2.58)\end{array}$ \\
\hline \multicolumn{9}{|c|}{ Age of pregnant person $>35 \mathrm{yr}$} \\
\hline $\begin{array}{l}\text { Any hypertensive } \\
\text { disorder of pregnancy }\end{array}$ & 3695 & $\begin{array}{c}1.31 \\
(0.99-1.72)\end{array}$ & $\begin{array}{c}1.09 \\
(0.83-1.44)\end{array}$ & $\begin{array}{c}1.09 \\
(0.83-1.44)\end{array}$ & 902 & $\begin{array}{c}1.76 \\
(1.08-2.88)\end{array}$ & $\begin{array}{c}1.50 \\
(0.92-2.45)\end{array}$ & $\begin{array}{c}1.39 \\
(0.85-2.28)\end{array}$ \\
\hline Pre-eclampsia & 4113 & $\begin{array}{c}1.23 \\
(0.94-1.61)\end{array}$ & $\begin{array}{c}1.00 \\
(0.76-1.31)\end{array}$ & $\begin{array}{c}1.00 \\
(0.76-1.32)\end{array}$ & 484 & $\begin{array}{c}2.70 \\
(1.60-4.56)\end{array}$ & $\begin{array}{c}1.99 \\
(1.18-3.37)\end{array}$ & $\begin{array}{c}1.82 \\
(1.08-3.08)\end{array}$ \\
\hline $\begin{array}{l}\text { Preterm pre- } \\
\text { eclampsiał }\end{array}$ & 651 & $\begin{array}{c}1.50 \\
(0.81-2.79)\end{array}$ & $\begin{array}{c}0.73 \\
(0.38-1.42)\end{array}$ & $\begin{array}{c}0.76 \\
(0.39-1.50)\end{array}$ & 112 & $\begin{array}{c}2.83 \\
(0.91-8.78)\end{array}$ & $\begin{array}{c}1.42 \\
(0.45-4.52)\end{array}$ & $\begin{array}{c}1.24 \\
(0.38-4.08)\end{array}$ \\
\hline
\end{tabular}

Note: $\mathrm{Cl}$ = confidence interval, $\mathrm{HR}=$ hazard ratio.

*The primary outcome is defined as a composite of any future hospital admission for heart failure, cardiac dysrhythmia, coronary artery disease, cerebrovascular disease or peripheral artery disease. †Adjusted for age at first birth, neighbourhood income quintile, world region of origin, assisted reproductive technology, and cardiovascular risk factors present at baseline before the first pregnancy. †Defined as pre-eclampsia with a preterm birth $<34$ weeks' gestation. 
mass rather than to vascular predisposition, the association between HDP with future maternal cardiovascular disease would be expected to be weaker than in people who have delivered singletons (Appendix 1, Appendix G). This explanation is further supported by previous studies reporting that the risk of recurrence of HDP in subsequent pregnancies is greater for people with a history of HDP in a singleton gestation (where HDP is likely to reflect vascular predisposition) than for those with a history of HDP in a twin gestation (where HDP is more likely to be the result of the transient risk factor such as increased placental mass). ${ }^{53}$

\section{Limitations}

The main limitations of our study are those inherent to the use of administrative databases that are based on diagnostic or billing codes to determine outcomes. Thus, cases with mild cardiovascular disease may not have been recorded. In addition, although we adjusted the analysis for multiple confounding variables, we could not rule out residual confounding, as data on certain cardiovascular risk factors, such as family history of cardiovascular disease and maternal body mass index, were not available. Furthermore, given the observational nature of the study, data on preventive interventions and risk reduction measures in those with a history of HDP were not available. ${ }^{3,12,54}$ Finally, despite the large sample size, the current study was underpowered to detect associations with the secondary outcomes in the twin group.

\section{Conclusion}

We found that compared with HDP in singleton pregnancies, HDP in twin pregnancies is less likely to be associated with future cardiovascular disease. This suggests that HDP in twin gestations is a weaker risk factor for future cardiovascular disease than HDP in singleton pregnancies. This has important implications for the counselling and risk stratification of cardiovascular risk, given the relatively high prevalence of HDP in twin gestations, as well as for the understanding of the mechanisms underlying HDP in twin compared with singleton pregnancies. Future studies should focus on the pathophysiology of HDP in twin compared with singleton pregnancies, and on the mechanisms underlying the association between HDP and future cardiovascular disease in these 2 groups.

\section{References}

1. Coutinho T, Lamai O, Nerenberg K. Hypertensive disorders of pregnancy and cardiovascular diseases: current knowledge and future directions. Curr Treat Options Cardiovasc Med 2018;20:56.

2. Go AS, Mozaffarian D, Roger VL, et al.; American Heart Association Statistics and Stroke Statistics Subcommittee. Heart disease and stroke statistics: 2014 update - a report from the American Heart Association. Circulation 2014;129:e28-292.

3. Mosca L, Benjamin EJ, Berra K, et al.; American Heart Association. Effectiveness-based guidelines for the prevention of cardiovascular disease in women: 2011 update - a guideline from the American Heart Association. J Am Coll Cardiol 2011;57:1404-23.

4. Andersgaard AB, Acharya G, Mathiesen EB, et al. Recurrence and long-term maternal health risks of hypertensive disorders of pregnancy: a populationbased study. Am J Obstet Gynecol 2012;206:143.e1-8.

5. Bergen NE, Schalekamp-Timmermans S, Roos-Hesselink J, et al. Hypertensive disorders of pregnancy and subsequent maternal cardiovascular health. Eur J Epidemiol 2018;33:763-71.
6. Tooher J, Thornton C, Makris A, et al. All hypertensive disorders of pregnancy increase the risk of future cardiovascular disease. Hypertension 2017; 70:798-803.

7. Tooher J, Thornton C, Makris A, et al. Hypertension in pregnancy and longterm cardiovascular mortality: a retrospective cohort study. Am J Obstet Gynecol 2016;214:722.e1-6.

8. Cunningham MW Jr, LaMarca B. Risk of cardiovascular disease, end-stage renal disease, and stroke in postpartum women and their fetuses after a hypertensive pregnancy. Am J Physiol Regul Integr Comp Physiol 2018;315:R521-8.

9. McDonald SD, Malinowski A, Zhou Q, et al. Cardiovascular sequelae of preeclampsia/eclampsia: a systematic review and meta-analyses. Am Heart $J$ 2008;156:918-30.

10. Paauw ND, Lely AT. Cardiovascular sequels during and after preeclampsia. Adv Exp Med Biol 2018;1065:455-70.

11. Canoy D, Cairns BJ, Balkwill A, et al.; Million Women Study Collaborators. Hypertension in pregnancy and risk of coronary heart disease and stroke: a prospective study in a large UK cohort. Int J Cardiol 2016;222:1012-8.

12. Anderson TJ, Grégoire J, Pearson GJ, et al. 2016 Canadian Cardiovascular Society guidelines for the management of dyslipidemia for the prevention of cardiovascular disease in the adult. Can J Cardiol 2016;32:1263-82.

13. Brosens I, Pijnenborg R, Vercruysse L, et al. The "Great Obstetrical Syndromes" are associated with disorders of deep placentation. Am J Obstet Gynecol 2011;204:193-201.

14. Cross JC, Werb Z, Fisher SJ. Implantation and the placenta: key pieces of the development puzzle. Science 1994;266:1508-18.

15. Lim KH, Zhou Y, Janatpour M, et al. Human cytotrophoblast differentiation/ invasion is abnormal in pre-eclampsia. Am J Pathol 1997;151:1809-18.

16. Roberts JM, Redman CW. Pre-eclampsia: more than pregnancy-induced hypertension. Lancet 1993;341:1447-51.

17. Makris A, Thornton C, Thompson J, et al. Uteroplacental ischemia results in proteinuric hypertension and elevated sFLT-1. Kidney Int 2007;71:977-84.

18. Salafia CM, Pezzullo JC, Ghidini A, et al. Clinical correlations of patterns of placental pathology in preterm pre-eclampsia. Placenta 1998;19:67-72.

19. Silasi M, Cohen B, Karumanchi SA, et al. Abnormal placentation, angiogenic factors, and the pathogenesis of preeclampsia. Obstet Gynecol Clin North Am 2010;37:239-53.

20. O'Brien M, Baczyk D, Kingdom JC. Endothelial dysfunction in severe preeclampsia is mediated by soluble factors, rather than extracellular vesicles. Sci Rep 2017;7:5887.

21. Korzeniewski SJ, Romero R, Chaiworapongsa T, et al. Maternal plasma angiogenic index-1 (placental growth factor/soluble vascular endothelial growth factor receptor-1) is a biomarker for the burden of placental lesions consistent with uteroplacental underperfusion: a longitudinal case-cohort study. Am J Obstet Gynecol 2016;214:629.e1-17.

22. Redman CWG, Sargent IL. Preeclampsia and the systemic inflammatory response. Semin Nephrol 2004;24:565-70.

23. Young BC, Levine RJ, Karumanchi SA. Pathogenesis of preeclampsia. Annu Rev Pathol 2010;5:173-92.

24. Maynard S, Epstein FH, Karumanchi SA. Preeclampsia and angiogenic imbalance. Annu Rev Med 2008;59:61-78.

25. Udell JA, Lu H, Redelmeier DA. Failure of fertility therapy and subsequent adverse cardiovascular events. CMAJ 2017;189:E391-7.

26. Hypertension in pregnancy. Report of the American College of Obstetricians and Gynecologists' Task Force on Hypertension in Pregnancy. Obstet Gynecol 2013;122:1122-31.

27. Chauhan SP, Scardo JA, Hayes E, et al. Twins: prevalence, problems, and preterm births. Am J Obstet Gynecol 2010;203:305-15.

28. Coonrod DV, Hickok DE, Zhu K, et al. Risk factors for preeclampsia in twin pregnancies: a population-based cohort study. Obstet Gynecol 1995;85:645-50.

29. Foo JY, Mangos GJ, Brown MA. Characteristics of hypertensive disorders in twin versus singleton pregnancies. Pregnancy Hypertens 2013;3:3-9.

30. Krotz S, Fajardo J, Ghandi S, et al. Hypertensive disease in twin pregnancies: a review. Twin Res 2002;5:8-14.

31. Magee LA, Pels A, Helewa M, et al.; SOGC Hypertension Guideline Committee. Diagnosis, evaluation, and management of the hypertensive disorders of pregnancy: executive summary. J Obstet Gynaecol Can 2014;36:575-6.

32. Santema JG, Koppelaar I, Wallenburg HC. Hypertensive disorders in twin pregnancy. Eur J Obstet Gynecol Reprod Biol 1995;58:9-13.

33. Sibai BM, Hauth J, Caritis S, et al. Hypertensive disorders in twin versus singleton gestations. National Institute of Child Health and Human Development Network of Maternal-Fetal Medicine Units. Am J Obstet Gynecol 2000; 182:938-42.

34. Laine K, Murzakanova G, Baker Sole K, et al. Prevalence and risk of preeclampsia and gestational hypertension in twin pregnancies: a populationbased register study. BMJ Open 2019;9:e029908. 
35. Bujold E, Romero R, Chaiworapongsa T, et al. Evidence supporting that the excess of the SVEGFR-1 concentration in maternal plasma in preeclampsia has a uterine origin. J Matern Fetal Neonatal Med 2005;18:9-16.

36. Dekker GA. Risk factors for preeclampsia. Clin Obstet Gynecol 1999; 42:422-35.

37. Bdolah Y, Lam C, Rajakumar A, et al. Twin pregnancy and the risk of preeclampsia: bigger placenta or relative ischemia? Am J Obstet Gynecol 2008;198:428.e1-6.

38. Bergman L, Nordlöf-Callbo P, Wikström AK, et al. Multi-fetal pregnancy, preeclampsia, and long-term cardiovascular disease. Hypertension 2020;76:167-75.

39. Baci Y, Üstüner I, Keskin HL, et al. Effect of maternal obesity and weight gain on gestational diabetes mellitus. Gynecol Endocrinol 2013;29:133-6.

40. Feig DS, Zinman B, Wang X, et al. Risk of development of diabetes mellitus after diagnosis of gestational diabetes. CMAJ 2008;179:229-34.

41. Joseph KS, Fahey J; Canadian Perinatal Surveillance System. Validation of perinatal data in the Discharge Abstract Database of the Canadian Institute for Health Information. Chronic Dis Can 2009;29:96-100.

42. Austin PC, Daly PA, Tu JV. A multicenter study of the coding accuracy of hospital discharge administrative data for patients admitted to cardiac care units in Ontario. Am Heart J 2002;144:290-6.

43. Hall R, Mondor L, Porter J, et al. Accuracy of administrative data for the coding of acute stroke and TIAs. Can J Neurol Sci 2016;43:765-73.

44. Norwitz ER, Edusa V, Park JS. Maternal physiology and complications of multiple pregnancy. Semin Perinatol 2005;29:338-48.

45. Kramer MS, Platt RW, Wen SW, et al.; Fetal/Infant Health Study Group of the Canadian Perinatal Surveillance System. A new and improved population-based Canadian reference for birth weight for gestational age. Pediatrics 2001;108:E35.
46. Ghossein-Doha C, van Neer J, Wissink B, et al. Pre-eclampsia: an impor tant risk factor for asymptomatic heart failure. Ultrasound Obstet Gynecol 2017;49:143-9.

47. Wu P, Haththotuwa R, Kwok CS, et al. Preeclampsia and future cardiovascula health: a systematic review and meta-analysis. Circ Cardiovasc Qual Outcomes 2017;10:e003497.

48. Cain MA, Salemi JL, Tanner JP, et al. Pregnancy as a window to future health: maternal placental syndromes and short-term cardiovascular outcomes. $A m \mathrm{~J}$ Obstet Gynecol 2016;215:484.e1-14

49. Refvik Riise HK, Sulo G, Tell GS, et al. Incident coronary heart disease after preeclampsia: role of reduced fetal growth, preterm delivery, and parity. J Am Heart Assoc 2017;6:e004158.

50. Tomimatsu T, Mimura K, Matsuzaki S, et al. Preeclampsia: maternal systemic vascular disorder caused by generalized endothelial dysfunction due to placental antiangiogenic factors. Int J Mol Sci 2019;20:4246.

51. Yinon Y, Kingdom JC, Odutayo A, et al. Vascular dysfunction in women with a history of preeclampsia and intrauterine growth restriction: insights into future vascular risk. Circulation 2010;122:1846-53.

52. Brennan LJ, Morton JS, Davidge ST. Vascular dysfunction in preeclampsia. Microcirculation 2014;21:4-14.

53. Trogstad L, Skrondal A, Stoltenberg C, et al. Recurrence risk of preeclampsia in twin and singleton pregnancies. Am J Med Genet A 2004;126A:41-5.

54. Graves M, Howse K, Pudwell J, et al. Pregnancy-related cardiovascular risk indicators: primary care approach to postpartum management and prevention of future disease. Can Fam Physician 2019;65:883-9.
Competing interests: Jon Barrett reports receiving fees for giving expert testimony on behalf of the Canadian Medical Protective Association. Howard Berger reports receiving human placenta growth factor (PLGF) analysis kits from Roche Diagnostics for a quality improvement study on PLGF use in obstetrics. No other competing interests were declared.

This article has been peer reviewed.

Affiliations: Division of Maternal-Fetal Medicine (Hiersch, Barrett, Melamed), Department of Obstetrics and Gynecology, Sunnybrook Health Sciences Centre, University of Toronto, Toronto, Ont.; Departments of Obstetrics and Gynaecology (Hiersch), Lis Maternity Hospital and Sackler Faculty of Medicine, Tel Aviv University, Tel Aviv, Israel; Departments of Medicine and Obstetrics and Gynaecology (Ray), St. Michael's Hospital, University of Toronto; ICES Central (Ray, Diong, Gandhi, Guan); Division of Maternal-Fetal Medicine (Berger, Geary), Department of Obstetrics and Gynecology, St. Michael's Hospital, University of Toronto, Toronto, Ont.; Division of MaternalFetal Medicine (McDonald, Murray-Davis), Departments of Obstetrics and Gynecology, Radiology, and Research Methods, Evidence \& Impact, McMaster University, Hamilton, Ont.

Contributors: Nir Melamed, Liran Hiersch, Joel Ray and Jon Barrett contributed to the conception and design of the work and the acquisition, analysis, and interpretation of data. All of the authors drafted the manuscript. Howard Berger, Michael Geary, Sarah McDonald, Christina Diong, Sima Gandhi, Jun Guan and Beth Murray-Davis revised it critically for important intellectual content. All of the authors gave final approval of the version to be published.

Content licence: This is an Open Access article distributed in accordance with the terms of the Creative Commons Attribution (CC BY-NC-ND 4.0) licence, which permits use, distribution and reproduction in any medium, provided that the original publication is properly cited, the use is noncommercial (i.e., research or educational use), and no modifications or adaptations are made. See: https://creativecommons. org/licenses/by-nc-nd/4.0/

Funding: This study was funded by Canadian Institute of Health Research (CIHR) (Grant\#146442; Non-communicable Diseases in Obstetrics: Improving Quality of Care and Maternal-infant Outcomes Through an Obstetrical Research Network). Dr. Melamed holds the Waugh Family Chair in Twin Fetal Medicine Research at the Sunnybrook Health Sciences Center and the University of Toronto. Dr. McDonald is supported by a Tier II Canada Research Chair (950-229920). The funders had no roles in the study design; the collection, analysis, or interpretation of data; the writing of the report; or the decision to submit the article for publication. We confirm the independence of the study researchers from the funders; and we confirm that all authors, external and internal, had full access to all the data in the study (including statistical reports and tables) and can take responsibility for the integrity of the data and the accuracy of the analysis.

Data sharing: The data set from this study is held securely in coded form at ICES. While legal data sharing agreements between ICES and data providers (e.g., health care organizations and government) prohibit ICES from making the data set publicly available, access may be granted to those who meet prespecified criteria for confidential access, available at https://www.ices.on.ca/DAS (email: das@ ices.on.ca). The full data set creation plan and underlying analytic code are available from the authors upon request, understanding that the computer programs may rely upon coding templates or macros that are unique to ICES and are therefore either inaccessible or may require modification.

Acknowledgement: The authors thank Ms. Negar Bagheri for assistance in project coordination. Parts or whole of this material are based on data and/or information compiled and provided by Immigration, Refugees and Citizenship Canada (IRCC) current to March 31, 2017. However, the analyses, conclusions, opinions and statements expressed in the material are those of the author(s), and not necessarily those of IRCC.

Disclaimer: No endorsement by ICES or the Ontario Ministry of Health and Long-Term Care is intended or should be inferred. Parts of this material are based on data and information compiled and provided by the Canadian Institute for Health Information. However, the analyses, conclusions, opinions, and statements expressed herein are those of the authors and not necessarily those of the Canadian Institute for Health Information.

Accepted: June 17, 2021

Correspondence to: Liran Hiersch, liranh@tlvmc.gov.il 